\title{
Water Relations, Growth, and Dry Matter Accumulation of Sorghum Under Post-Rainy Season Conditions ${ }^{1}$
}

\author{
M. V. K. Sivakumar, N. Seetharama, Sardar Singh, and F. R. Bidinger ${ }^{2}$
}

\begin{abstract}
Sorghum (Sorghum bicolor (L.) Moench) is one of the important crops grown under the residual soil moisture situation during the post-rainy (rabi) season in India. Field studies were conducted at the ICRISAT center on deep vertisols on the effects of water stress on the growth and dry matter accumulation of sorghum. Leaf water potential and stomatal conductance were measured diurnally on four dates during the growing season.

Irrigated sorghum crop exhibited higher stomatal conductance and higher leaf water potentials as compared to the nonirrigated sorghum. Higher transpiration rates observed in the case of the irrigated sorghum could be explained by the increased net radiation measured over the irrigated canopy. Lower leaves in the sorghum canopy showed lower stomatal conductance. Irrigated sorghum plants showed higher leaf area index and greater dry matter accumulation than those of the nonirrigated sorghum plants. There were significant differences in the final yield between the two treatments as reflected by less teritiary branches/secondaries, lower seed number/panicle and smaller seed size in the case of the nonirrigated sorghum.

On a seasonal basis, the nonirrigated sorghum crop used $213 \mathrm{~mm}$ of water to produce $0.51 \mathrm{~kg} \mathrm{~m}^{-2}$ of dry matter, whereas the irrigated sorghum extracted $321 \mathrm{~mm}$ of water to produce $0.93 \mathrm{~kg} \mathrm{~m}^{-2}$ of dry matter.
\end{abstract}

Additional index words: Leaf-water potential, Stomatal conductance, Leaf area index, Water use.

$\mathbf{P}_{\mathrm{t}}^{\mathrm{L}}$ LANT growth is the resultant of an effective integration of many factors. Restriction of growth may occur due to the limitation of any one factor; for example, water deficits in plants generally lead to reduced leaf water potentials and stomatal closure, as manifested from an increased leaf resistance to transpiration. The effects of depletion and replenishment of soil water on transpiration are of specific importance to water use and its efficiency in crop production. The relative rates of absorption and transpiration determine a plant's internal water balance, which directly affects the physiological and biochemical processes of plant growth (Teare and Kanemasu, 1972).

In a field study, Ehrler and van Bavel (1967) showed that limited soil water availability led to increased daytime values of leaf diffusion resistance and decreased evapotranspiration in contrast to the values for plants having water freely available. Working with wheat (Triticum aestivum L.) in growth chambers, Frank et al. (1973) concluded that recovery of photosynthesis in stressed plants was related to stomatal diffusion resistance at tillering and heading, but that photosynthesis never fully recovered to its pre-stress

\footnotetext{
${ }^{1}$ Authorzied for publication as ICRISAT Journal Article 39 Received 5 Mar. 1979.

${ }^{2}$ Agroclimatologist, crop physiologist, soil physicist, and crop physiologist, respectively, ICRISAT, 1-11-256, Begumpet, Hyderabad-500016, A.P. India.

Mention of commercial products or companies does not imply endorsement or recommendation by ICRISAT over others of similar nature.
}

levels. Photosynthesis of plants stressed at grain filling showed no sign of recovery due to stress-induced senescence. Teare and Kanemasu (1972) asserted that even though atmospheric demand for water was similar for soybeans (Glycine max (L.) Merr.) and sorghum (Sorghum bicolor L.), sorghum was able to close its stomata more frequently than soybeans, reduce its transpiration, and thus conserve soil water.

Sorghum is one of the important crops grown during the post-rainy (rabi) season in India. Crops grown in this season depend primarily on residual soil moisture, so it will be useful to understand the plant response to changing soil moisture environment. Characterization of the plant water stress by measuring the leaf water potential and conductance and by studying crop response to water stress in terms of the growth and dry matter accumulation of sorghum was the primary objective of this study.

\section{MATERIALS AND METHODS}

The experiment was conducted at the ICRISAT Center near Hyderabad, India $\left(17^{\circ} 32^{\prime} \mathrm{N}\right.$ Lat $78^{\circ} 16^{\prime} \mathrm{E}$ Long) during the post rainy season of 1977 (October 1977 through February 1978) on a deep Vertisol. This is a very fine, clayey, montmorillonitic, calcareous, hyperthermic member of the family of typic Pallusterts. The upper limit of water availability, determined in situ, averaged $0.44 \mathrm{~cm}^{3} / \mathrm{cm}^{3}$ and the lower limit averaged 0.27 $\mathrm{cm}^{3} / \mathrm{cm}^{3}$.

The experiment was laid out in a randomized block design with three replications. Each replicate consisted of two $10-\times$ 20-m plots. One plot in each replication was irrigated on 18 November and 17 December (29 and 58 days after planting) with 8 and $11 \mathrm{~cm}$, respectively. Sorghum CSH-8 was sown in $45 \cdot \mathrm{cm}$ rows on 20 October. The final plant population was 180,000 plants/ha.

Beginning 12 days after planting, abovc-ground whole plants from a $2.7-\mathrm{m}^{2}$ area in each plot were sampled at 8 - to 10-day intervals. After plant height was measured, each plant was separated into leaves, stems, and heads. Leaf area of a subsample was measured with an automatic leaf-area meter (Hayashi Denkoh Co. Ltd., Tokyo, Japan). Plant parts were dried to constant weight in a forced draft oven at $65 \mathrm{C}$ and weighed.

Stomatal resistance measurements were taken with a diffusion porometer c :ibrated before each set of field measurements. Resistance measurements were taken from 0600 to 2000 hours at hourly intervals on four dates during the growing season. At each time interval, measurements were taken in the irrigated (I) and nonirrigated (UI) plots on adaxial ( $\left.R_{a d}\right)$ and abaxial $\left(R_{a b}\right)$ sides of five different leaves in three stratified layers within the canopy. The total leaf resistance $\left(R_{\text {lest }}\right)$ was calculated as:

$$
\frac{1}{\mathbf{R}_{\text {leat }}}=\frac{1}{\mathbf{R}_{\mathrm{ad}}}+\frac{1}{\mathbf{R}_{\mathrm{ab}}}
$$

Stomatal conductance is expressed as the reciprocal of the leaf stomatal resistance.

Leaf water potentials were measured with a pressure chamber (Scholander et al., 1965). Daily values of maximum and minimum air temperature, precipitation, open-pan evaporation, and wind speeds were measured in a standard weather station $250 \mathrm{~m}$ southwest of the plot areas. Incoming solar radiation was measured at hourly intervals with a pyranometer sensor (LI200S, LAMBDA Instruments Corporation, Lincoln, Nebr) ${ }^{3}$ attached to an LI-500 integrator. Wet and dry bulb temperatures 
Table 1. Meteorological parameters during the postrainy season at ICRISAT Center, 1977.

\begin{tabular}{|c|c|c|c|c|c|c|}
\hline \multirow[b]{2}{*}{ Month } & \multicolumn{2}{|c|}{ Avg. temperature } & \multirow{2}{*}{$\begin{array}{c}\text { Total } \\
\text { precipi- } \\
\text { tation }\end{array}$} & \multirow{2}{*}{$\begin{array}{l}\text { Avg. } \\
\text { 24-hour } \\
\text { winds }\end{array}$} & \multirow{2}{*}{$\begin{array}{l}\text { Avg. } \\
\text { solar } \\
\text { radiation }\end{array}$} & \multirow{2}{*}{$\begin{array}{c}\text { Avg. pan } \\
\text { evapora- } \\
\text { tion }\end{array}$} \\
\hline & $\begin{array}{l}\text { Max- } \\
\text { imum }\end{array}$ & $\begin{array}{l}\text { Min- } \\
\text { imum }\end{array}$ & & & & \\
\hline & $\longrightarrow$ & $\longrightarrow$ & $\mathrm{cm}$ & $\mathrm{km} / \mathrm{hour}$ & ly/day & $\mathrm{cm} /$ day \\
\hline $\begin{array}{l}20 \text { Oct. } \\
\text { Nov. } \\
\text { Dec. } \\
\text { Jan. } \\
6 \text { Feb. }\end{array}$ & $\begin{array}{l}31.2 \\
29.1 \\
27.6 \\
27.9 \\
28.5\end{array}$ & $\begin{array}{l}17.9 \\
20.5 \\
12.9 \\
15.8 \\
18.1\end{array}$ & $\begin{array}{c}-- \\
2.78 \\
0.20 \\
0.07 \\
0.28\end{array}$ & $\begin{array}{r}6.7 \\
9.4 \\
6.6 \\
8.9 \\
12.3\end{array}$ & $\begin{array}{l}474 \\
346 \\
377 \\
240 \\
363\end{array}$ & $\begin{array}{l}0.61 \\
0.45 \\
0.47 \\
0.48 \\
0.57\end{array}$ \\
\hline
\end{tabular}

were recorded at hourly intervals using an Assman type psychrometer. Hourly values of windspeed were recorded with a counter system attached to a sensitive anemometer (Science Associates, New Jersey) $)^{3}$ mounted $1 \mathrm{~m}$ above the canopy. Hourly values of net radiation were obtained from two SWISSTECO net radiometers mounted $1 \mathrm{~m}$ above the sorghum canopy in the irrigated and nonirrigated plots.

A neutron probe was used throughout the growing season to measure moisture depletion from the soil. Measurements were made at 22-, 37-, 52-, 67-, 82-, 97-, 112-, 142-, 157-, 172-, and 187 . $\mathrm{cm}$ depths at four locations in each plot in the three replications. Gravimetric measurements were taken in the top $2 \mathrm{~cm}$ of soil. Volumetric moisture content values for each treatment are averaged over 12 neutron readings.

\section{RESULTS AND DISCUSSION}

The plots were sown on 20 October. A $17-\mathrm{mm}$ rain on 1 and 2 November helped to establish a good stand. A summary of the meteorological data for the growing season is presented in Table 1. December, January, and February were characteristically dry. Because only $5 \mathrm{~mm}$ of rain fell during these months, the nonirrigated plots experienced severe water stress, especially during January.

Changes in available soil water $(\mathrm{mm})$ in different soil depths during the growing season in the irrigated and nonirrigated plots are plotted in Fig. Ia and $\mathrm{Ib}$. The first irrigation of $8 \mathrm{~cm}$ was given on 18 November, 29 days after planting. The second irrigation of $11 \mathrm{~cm}$ was given 58 days after planting, on 17 December. The differences in available water contents in different layers of soil between the two treatments are quite apparent, especially after the irrigation. The data presented show that in the irrigated plots a significant amount of water is available in the top $82 \mathrm{~cm}$ of soil depth. In the case of nonirrigated sorghum, rapid extraction was observed in the top $82 \mathrm{~cm}$ during the first 55 days after planting. Starting from 33 days after planting, the top 0 - to $22-\mathrm{cm}$ layer showed no available water. During the period of 22 November to 16 December, irrigated sorghum extracted $118 \mathrm{~mm}$ of water from the $187 \cdot \mathrm{cm}$ soil profile, as opposed to only $64 \mathrm{~mm}$ by the nonirrigated sorghum ${ }^{4}$.

Although measurements were taken in all four sets, only those two sets of stomatal conductance and water potential measurements taken on 20 December and 16 January are presented here to delineate the effects of differential water extraction rates of the irrigated and nonirrigated sorghum. The diurnal variation in the

* M. B. Russell and Sardar Singh. 1978. Water use by maize, sorghum, pigeonpea, and chickpea from a deep Vertisol. Submitted for publication. microclimatic data as related to stomatal conductance and leaf water potential on 20 December is plotted in Fig. 2. The data establish clear differences in the stomatal conductance and leaf water potential between the two treatments. Irrigated sorghum exhibited higher stomatal conductance with values $>0.5 \mathrm{~cm} / \mathrm{sec}$ during most of the day, indication, perhaps, of better photosynthetic activity than the nonirrigated sorgh.um canopies which showed stomatal closure much earlier than the irrigated sorghum plants. Irrigated sorgh.um leaf water potentials never exceeded - 13 bars; the nonirrigated sorghum showed leaf water potentials lower than -15 bars from 1000 to 1700 hours. With increasing energy flux, the leaf water potentials in both the treatments decreased up to 1300 hours. A slight lag between the drop in the energy flux and recovery of leaf-water potentials could be observed. In case of irrigated sorghum, stomatal conductance showed a close relationship with the diurnal changes in the incident radiation. This relationship was not observed in the non-irrigated sorghum canopy. Similar relations between conductance and radiation were recorded by Turner (1974) with sorghum and Sivakumar and Shaw (1978a) with soybeans.

Diurnal variation in the net radiation over the irrigated and nonirrigated sorghum canopy on $20 \mathrm{De}$ cember is shown in Fig. 3. Irrigated sorghum canopy showed higher net radiation than the nonirrigated sorghum because of lower albedo and surface temperature. Integrated over the day, the difference in net

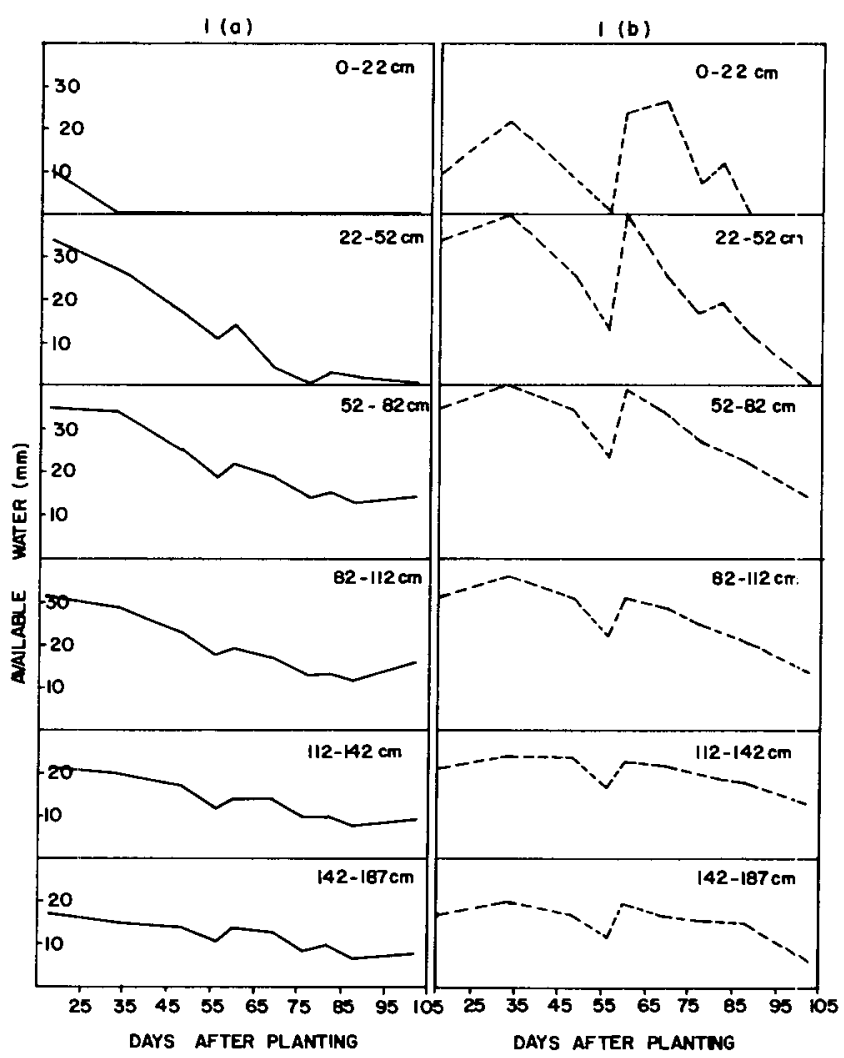

Fig. 1. Change in available soil water in different layers as a function of time during the growing season for (a) nonirrigated sorghum and (b) irrigated sorghum. 
radiation between the two treatments is about 31 ly/ $\mathrm{da}$, which could account for more than $0.5 \mathrm{~mm}$ of the higher transpiration rate in the irrigated sorghum as compared to the nonirrigated sorghum. Higher transpiration rates were recorded in the case of irrigated sorghum by Russell and Singh ${ }^{4}$.

Time of day has significant effect on stomatal activity. Fig. 4a shows the diurnal variation in stomatal conductance in different layers in nonirrigated sorghum. Stomatal conductance in the $30-$ to $60-\mathrm{cm}$ layer rarely exceeded $0.3 \mathrm{~cm} / \mathrm{sec}$, whereas the leaves in the 60 - to $90-\mathrm{cm}$ layer consistently showed less than 0.1 $\mathrm{cm} / \mathrm{sec}$. Teare and Kanemasu (1972) and Turner (1974) also showed that lower leaves in the sorghum canopy had higher resistance values. In the top canopy layers, stomata opened early in the irrigated plots and were open until 1600 hours (Fig. 4b). Diurnal variations in the bottom $30-$ to $60-\mathrm{cm}$ and 60 - to 90-cm layers showed conductance values much lower in magnitude than those of the top layer. Sorghum leaves in the bottom 60 - to $90-\mathrm{cm}$ layer did not show
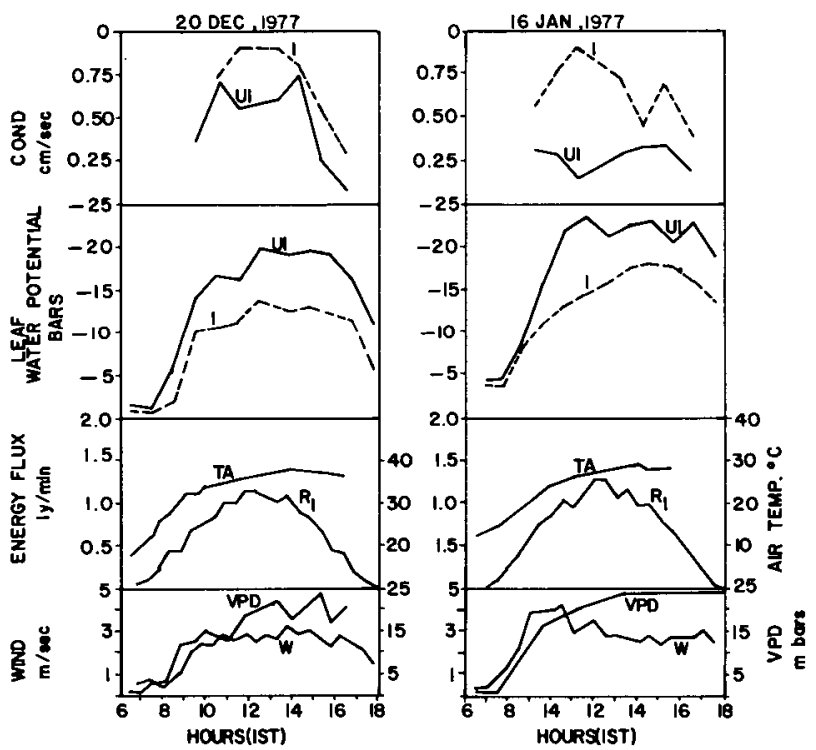

Fig. 2. Diurnal variation in the wind speed (W) Air temperature $\left(T_{A}\right)$, and radiation $\left(R_{I}\right)$ as related to stomatal conductance and leaf water potential on 2 days, for irrigated (I) and nonirrigated (UI) sorghum. conductance values $>0.3 \mathrm{~cm} / \mathrm{sec}$, probably due to the lower radiation at that level.

The leaf-area index (LAI) and dry matter accumulation data in Table 2 for the period 22 November to 16 December also show the advantage of the better water supply for the irrigated sorghum. The irrigated sorghum plants were taller and showed higher leaf area index and greater dry matter accumulation rates than those of the nonirrigated sorghum plants. Water extraction by irrigated sorghum from 22 November to 8 December and 8 to 16 December were 61 and $56 \mathrm{~mm}$, compared with only 35 and $28 \mathrm{~mm}$ for the same intervals for the nonirrigated sorghum. The higher stomatal conductance and less negative leaf
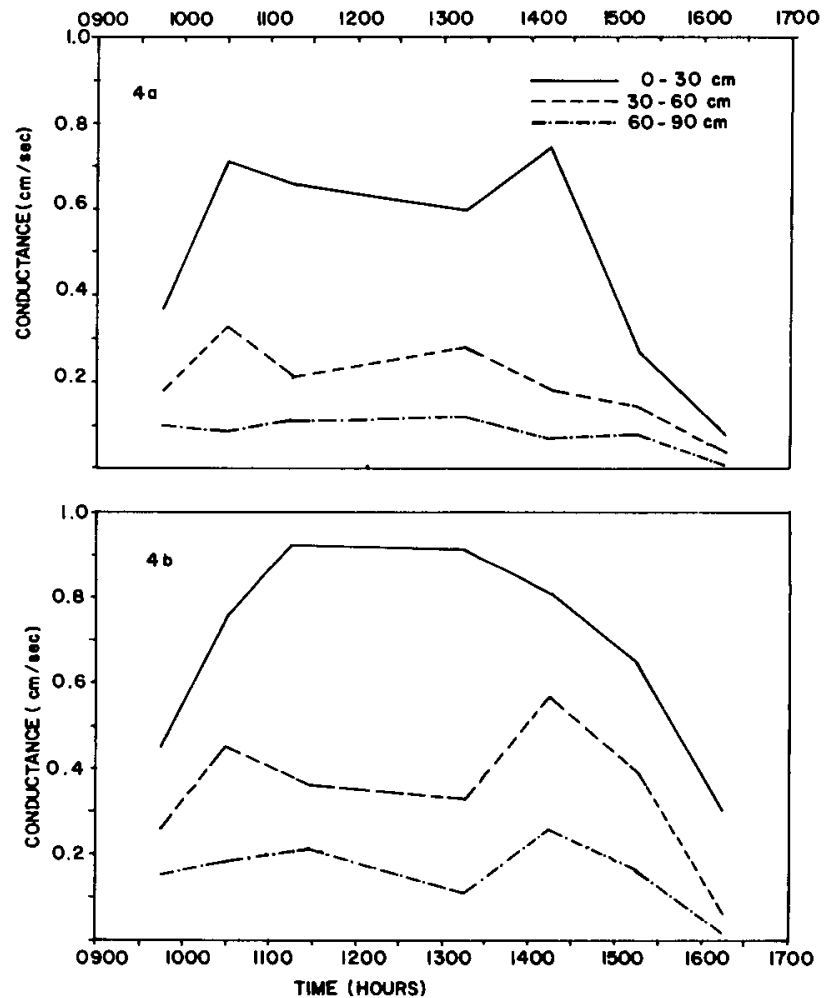

Fig. 4. Diurnal variation in the leaf conductance in different layers within the canopy for (a) nonirrigated sorghum and (b) irrigated sorghum.

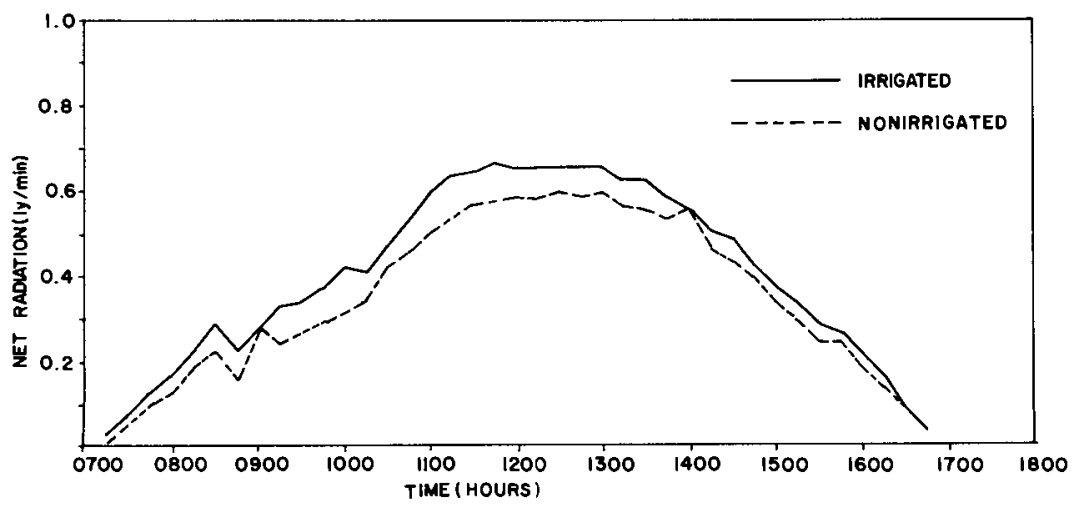

Fig. 3. Diurnal variation in the net radiation over an irrigated and nonirrigated sorghum canopy on 20 Dec. 1977. 
water potentials were associated with the higher dry matter production rates of the irrigated plots because plant turgidity is important in relation to the opening and closing stomata, expansion of leaves and flowers and movement of water and nutrients to various parts of the plant (Kramer, 1969).

A second irrigation of $11 \mathrm{~cm}$ was given on 17 December. Except for a $0.7-\mathrm{mm}$ rain on 10 January the period from 20 December to 2 February was completely dry. Total water extraction from 17 December to 16 January was $117 \mathrm{~mm}$ from the irrigated plots, whereas the nonirrigated sorghum plants extracted 96 $\mathrm{mm}$ during that period. The rate of extraction by the irrigated sorghum was similar to that of 22 November to 6 December. The nonirrigated sorghum showed a slightly higher rate than that of the earlier period.

Diurnal variation in the stomatal conductance and leaf water potential for 16 January is also shown in Fig. 2. Stomatal conductance of the irrigated sorghum plants increased up to 1100 hours but showed a steep decline afterwards. The conductance for the nonirrigated sorghum plants remained low throughout the day. Leaf water potentials of -22 bars after 1000 hours showed that the nonirrigated sorghum was under severe water stress. Irrigated sorghum showed a continuous decrease in leaf water potential up to a value of -18 bars at 1500 hours. Afterwards there was a slight daytime recovery in leaf turgor. Such a recovery was less evident in the nonirrigated sorghum plants. Stomatal conductance of the irrigated plants followed closely the diurnal pattern of the incoming radiation, indicating that the stomata were not completely closed. But the diurnal curve for the nonirrigated sorghum showed no such relationship, thereby showing complete stomatal closure. This conclusion was corroborated by the fairly constant leaf water potentials. It appears, therefore, that under severe water deficit, internal water status rather than atmospheric demand controlled the diurnal fluctuations in leaf water potentials ${ }^{\mathbf{5}}$.

Diurnal variations in the leaf conductance on 16 January in different layers within the canopy of irrigated sorghum are shown in Fig. $5 \mathrm{~b}$. It is apparent

${ }^{5}$ M. V. K. Sivakumar and R. H. Shaw. 1978. Plant water relations of soybeans as related to microclimate under moisture stress. Unpublished manuscript. that stomata were less active than they were on 20 December (Fig. 4b). Leaves in the 60- to $90-\mathrm{cm}$ layer showed complete stomatal closure. In nonirrigated sorghum striking differences in stomatal activity between 20 December and 16 January could be seen (Fig. $4 \mathrm{a}$ and $5 \mathrm{a}$ ). By 16 January, most of the leaves in the $30-$ to $60-\mathrm{cm}$ canopy layers in the nonirrigated plots were dry. Even the leaves in the top $30-\mathrm{cm}$ layer were partially dry and showed some stomatal closure.

Growth data (Table 2) for the 30 December to 16 January period showed significant differences between the irrigated and nonirrigated sorghum. Leaf area index and leaf dry weights of irrigated sorghum were higher. The differences in the dry weight of heads were even more pronounced; the weight of head of the irrigated sorghum was twice that of the nonirrigated crop. The total dry weights also showed highly significant differences between the two treatments.

The crop was harvested on 6 February. Irrigated sorghum grain yields were $5,990 \mathrm{~kg} / \mathrm{ha}$ compared to $2,430 \mathrm{~kg} / \mathrm{ha}$ for the nonirrigated crop. The major components of yield which were significantly affected by drought in the case of the nonirrigated plots were teritiary branches/secondaries, seed number/panicle, and seed size. The degree of reduction in these components over the irrigated plots was 46,26 , and $28 \%$, respectively.

\section{CONCLUSIONS}

Data presented in this study bring out the importance of the availability of a few additional $\mathrm{cm}$ of water to a sorghum crop under water stress and the benefits that could be accrued from such water applications. The modifications in the stomatal behavior and leafwater potential brought about by supplemental irrigation resulted in substantially high growth rates and yield. Sivakumar and Shaw (1978,b) showed that soybean growth rates were related to stomatal conductance and leaf water potential.

Under conditions of moderate water availability, the stomates of most plants open when the sun rises and remain open until sundown. But under moisture stress (when an imbalance develops between supply and demand for water), guard cells become less turgid and stomates begin to close. With the resultant decreasing supply of $\mathrm{CO}_{2}$ to the photosynthesis sites, there is a

Table 2. Height, leaf area index, and dry matter accumulation of irrigated (I) and nonirrigated (UI) sorghum during the growing season, ICRISAT Center, 1977.

\begin{tabular}{|c|c|c|c|c|c|c|c|c|c|c|c|c|}
\hline \multirow{3}{*}{$\begin{array}{l}\text { Days after } \\
\text { planting }\end{array}$} & \multirow{2}{*}{\multicolumn{2}{|c|}{ Height }} & \multirow{2}{*}{\multicolumn{2}{|c|}{ Leaf area index }} & \multicolumn{8}{|c|}{ Dry matter } \\
\hline & & & & & \multicolumn{2}{|c|}{ Leaf } & \multicolumn{2}{|c|}{ Stem } & \multicolumn{2}{|c|}{ Head } & \multicolumn{2}{|c|}{ Total } \\
\hline & I & UI & I & UI & I & UI & I & UI & I & UI & I & UI \\
\hline & \multicolumn{2}{|c|}{$\mathrm{cm}$} & & & \multicolumn{6}{|c|}{$-g / m^{2}$} & & \\
\hline 12 & - & - & 0.01 & 0.01 & 0.8 & 0.8 & 0.8 & 0.8 & -- & - & 1.6 & $1 . \epsilon_{i}$ \\
\hline 20 & - & - & 0.49 & 0.45 & 12.7 & 14.1 & 8.7 & 9.3 & .. & - & 21.4 & 23.4: \\
\hline 30 & - & -- & 1.44 & 1.80 & 43.4 & 58.7 & 37.2 & 37.8 & - & - & 80.6 & $96 . E_{1}$ \\
\hline 40 & -- & - & 2.56 & 2.78 & 102.4 & 107.3 & 90.1 & 125.6 & .. & -- & 192.5 & $232 . c_{1}$ \\
\hline 51 & 115.3 & 107.3 & 2.60 & 2.21 & 115.3 & 100.1 & 179.5 & 154.4 & .- & -- & 294.8 & 254.5 \\
\hline 60 & 125.7 & 94.3 & 2.70 & 2.42 & 132.6 & 119.6 & 231.9 & 196.4 & 79.3 & 73.1 & 443.8 & 389.01 \\
\hline 69 & 140.0 & 100.7 & 2.35 & 2.10 & 136.3 & 121.3 & 308.7 & 243.1 & 95.5 & 89.7 & 540.5 & 454.1 \\
\hline 79 & 170.3 & 97.0 & 3.49 & 3.08 & 170.5 & 129.2 & 367.8 & 263.9 & 203.9 & 176.5 & 742.2 & 569.6 \\
\hline 88 & 167.7 & 101.7 & 3.22 & 2.08 & 178.6 & 120.8 & 372.7 & 211.9 & 379.9 & 177.9 & 931.2 & 510.6 \\
\hline 100 & 168.3 & 98.3 & 1.02 & 0.31 & 144.7 & 117.0 & 274.1 & 170.7 & 509.0 & 290.0 & 927.8 & 577.7 \\
\hline
\end{tabular}



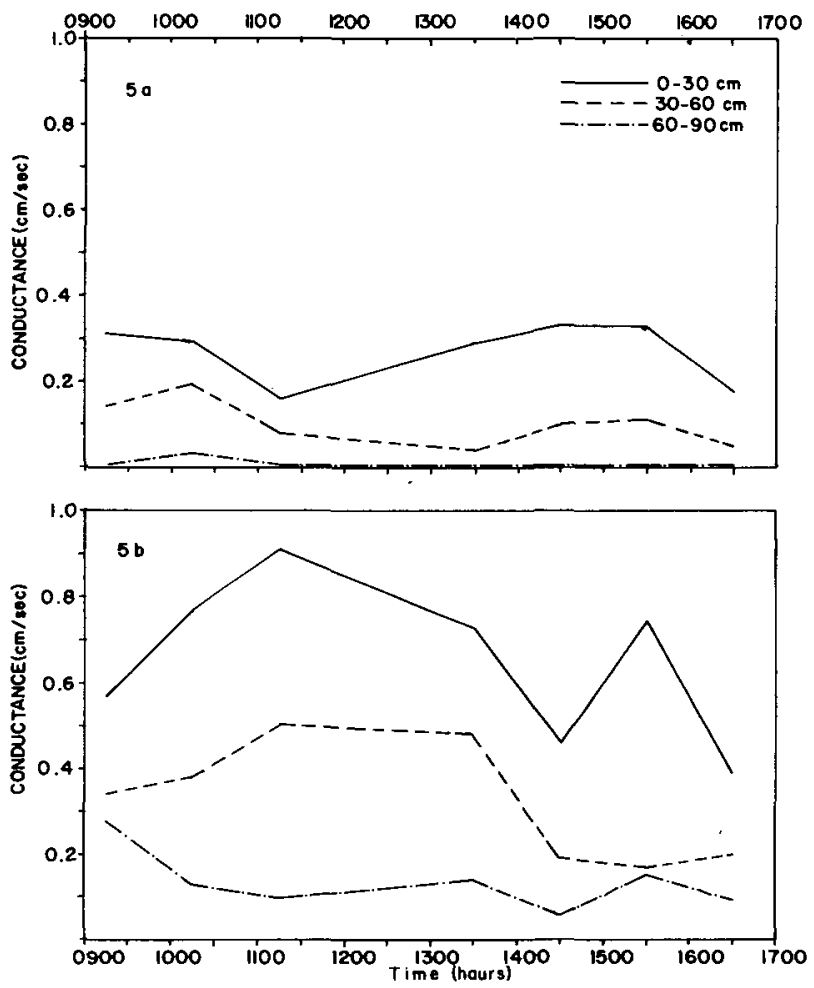

Fig. 5. Diurnal variation in leaf conductance in different layers within the canopy for (a) nonirrigated sorghum and (b) irrigated sorghum.

decrease in the photosynthetic activity, resulting in slow dry matter accumulation.

The first irrigation was given on 18 November $(29$ days after planting). The water-use efficiency was extremely low. Ritchie (1974) observed that growth rates at this stage were slow and a relatively large fraction of the evaporative flux was from the soil surface in comparison to the amount from plant surfaces. Shipley et al. (1971) reported that in irrigated grain sorghum, dry matter production was slowest from emergence to the six- to eight-leaf stage and from bloom to milk stage and was most rapid during the early to late boot stage. The second irrigation was given at heading. Growth rates were higher and grain yield was maximum in the irrigated plots because of the $11 \mathrm{~cm}$ of supplemental water. Musick and Dusek (1971) also found that in the Texas high plains a single 10-cm irrigation applied at heading or milk stage gave maximum yields. Szeicz et al. (1973) also noted that by means of irrigation to maintain stomatal resist- ance to a minimum, it is possible to increase yields by about $100 \%$, significantly improving the efficiency of water use. Rainfall during the growing season was very low and, in the case of stressed sorghum, dry matter production and grain yields were low because of low rates of stomatal conductance and reduced transpiration. Similar observations were recorded by Ritchie and Burnett (1971).

On a seasonal basis in the present study, the nonirrigated sorghum crop used $213 \mathrm{~mm}$ of water to produce $0.51 \mathrm{~kg} \mathrm{~m}^{-2}$ of dry matter, whereas the irrigated sorghum extracted $321 \mathrm{~mm}$ of water to produce $0.93 \mathrm{~kg}$ $\mathrm{m}^{-2}$ of dry matter. Szeicz et al. (1973) observed that average sorghum crops in Texas use about $320 \mathrm{~mm}$ of water throughout the growing season to produce around $0.8 \mathrm{~kg}$ dry matter $/ \mathrm{m}$.

\section{ACKNOWLEDGMENTS}

ICRISAT receives support from IBRD, IDRC, UNDP, USAID and a variety of other donors, governments, and foundations. All responsibility for the information in this publication rests with ICRISAT.

\section{LITERATURE CITED}

Ehrler, W. L., and C. H. M. van Bavel. 1967. Sorghum foliar responses to changes in soil water content. Agron. J. 59:243246.

Frank, A. B., J. F. Power, and W. O. Willis. 1973. Effect of temperature and plant water stress on photosynthesis, diffusion resistance, and leaf water potential in spring wheat. Agron. J. 65:777-780.

Kramer, P. J. 1969. Plant and soil water relationships: A modern synthesis. McGraw-Hill, New York.

Musick, J. T., and D. A. Dusek. 1971. Grain sorghum response to number, timing, and size of irrigation in the southern high plains. Trans. Am. Soc. Agric. Eng. 14:401-404.

Ritchie, J. T. 1974. Atmospheric and soil water influences on the plant water balance. Agric. Meteorol. 14:183-198.

- - , and E. Burnett. 1971. Dryland evaporative flux in a sub-humid climate. II, Plant influences. Agron. J. 63:56-62.

Scholander, P. F., H. T. Hammel, E. D. Bradstreet, and E. A. Hemmengsen. 1965. Sap pressure in vascular plants. Science 148:339-346.

Shipley, J., P. Unger, and C. Reiger. 1971. Consumptive water use, harvestable dry matter production, and nitrogen uptake by irrigated grain sorghum. Texas Agric. Exp. Stn. Prog. Rep.

No. 2951 . Texas A \& M Univ,, College Station, Tex.

Sivakumar, M. V. K., and R. H. Shaw. 1978a, Leaf response to water deficits in soybeans. Physiol. Plant. 42:134-139.

- - - and - - - $1978 \mathrm{~b}$. Relative evaluation of water stress indicators for soybeans. Agron. J. 70:619-623.

Szeicz, G., C. H. M. van Bavel, and S. Takami. 1973. Stomatal factor in the water use and dry matter production by sor. ghum. Agric. Meteorol. 12:361-389.

Teare, I. D., and E. T. Kanemasu. 1972. Stomatal - diffusion resistance and water potential of soybean and sorghum leaves. New Phytol. 71:805-810.

Turner, N. C. 1974. Stomatal behaviour and water status of Maize, Sorghum and Tobacco under field conditions. Plant Physiol. 53:360-365. 